University of Nebraska - Lincoln

DigitalCommons@University of Nebraska - Lincoln

Development of Maize Weevils (Coleoptera: Curculionidae) on Corn Lines Resistant to an Aflatoxin-Producing Fungus

James E. Throne

USDA-ARS, Manhattan, KS, james.throne@ars.usda.gov

James E. Baker

USDA-ARS

Gene E. Scott

USDA-ARS

Follow this and additional works at: https://digitalcommons.unl.edu/usdaarsfacpub

Throne, James E.; Baker, James E.; and Scott, Gene E., "Development of Maize Weevils (Coleoptera: Curculionidae) on Corn Lines Resistant to an Aflatoxin-Producing Fungus" (1995). Publications from USDA-ARS / UNL Faculty. 1996.

https://digitalcommons.unl.edu/usdaarsfacpub/1996

This Article is brought to you for free and open access by the U.S. Department of Agriculture: Agricultural Research Service, Lincoln, Nebraska at DigitalCommons@University of Nebraska - Lincoln. It has been accepted for inclusion in Publications from USDA-ARS / UNL Faculty by an authorized administrator of DigitalCommons@University of Nebraska - Lincoln. 


\title{
Development of Maize Weevils (Coleoptera: Curculionidae) on Corn Lines Resistant to an Aflatoxin-Producing Fungus
}

\author{
JAMES E. THRONE, ${ }^{1}$ JAMES E. BAKER, ${ }^{1}$ AND GENE E. SCOTT ${ }^{2}$ \\ Stored-Product Insects Research and Development Laboratory, USDA-ARS, 3401 Edwin Street, \\ Savannah, GA 31405
}

\begin{abstract}
Environ, Entomol. 24(4): 944-949 (1995)
ABSTRACT Susceptibility to the maize weevil, Sitophilus zeamais Motschulsky, of com lines bred for their resistance to the aflatoxin-producing fungus Aspergillus flavus Link ex Fries was determined in the laboratory. Duration of maize weevil development, number of progeny produced, and an index of susceptibility varied with com line; number of eggs laid and survivorship from egg to adult emergence did not vary with corn line. Soluble carbohydrate, kernel hardness, lipid, soluble nitrogen, free and bound phenolic acids, Kjeldahl protein, and protein/carbohydrate ratio varied with corn line; equilibrium moisture content did not vary with corn line. The only relationship between biological parameters of maize weevils and chemical and physical properties of the stored corn that was predictable was that maize weevil development time increased as lipid content of the com increased. Susceptibility to A. flavus infection in the field was not correlated with susceptibility to maize weevil population growth or with chemical or physical properties of the stored corn. Predicted weevil population growth over a 180-d period varied 50-fold among the corn lines. Some of the com lines that are less susceptible to infection by $A$. flavus in the field were also less susceptible to maize weevils (particularly Mp420 and SC54).
\end{abstract}

KEY WORDS Sitophilus zeamais, aflatoxin, host plant resistance

INFECTION OF CORN, Zea mays L., kernels by aflatoxin-producing fungi is a chronic problem in the southeastern United States. Development of com varieties resistant to aflatoxin-producing fungi is 1 method for reducing aflatoxin contamination of corn (Scott and Zummo 1988). However, most studies have concentrated only on resistance of preharvest corn to infection by aflatoxin-producing fungi, particularly Aspergillus flavus Link ex Fries. Dowd (1994) showed that an A. flavus resistant corn line (Mp313e) was cross resistant to insect vectors, Carpophilus hemipterus (L.) and C. freemani Dobson (Coleoptera: Nitidulidae), of $A$. $f(a-$ vus in preharvest corn. Damage to stored corn by insects may increase $A$. flavus infection by providing a path for entry into the kernel and by increasing moisture content of the kernel (Sinha and Sinha 1992). Therefore, development of corn lines resistant both to infection by aflatoxin-producing fungi and storage insects is desirable for reducing aflatoxin contamination of stored corn.

Resistance of corn to insects and fungi may be associated with physical and chemical characteris-

\footnotetext{
This article reports the results of research only. Mention of a proprietary product does not constitute an endorsement or a recommendation for its use by USDA.

'U.S. Grain Marketing Research Laboratory, USDA-ARS, 1515 College Avenue, Manhattan, KS 66502.

${ }^{2}$ Corn Host Plant Resistance Research Unit, USDA-AliS, P.O.B. 5248, Mississippi State, MS 39762.
}

tics of the corn. Resistance to the maize weevil, Sitophilus zeamais Motschulsky, an insect pest of stored corn has been associated with increased ferulic acid content of corn (Classen et al. 1990). Resistance to Fusarium graminearum Schwabe, a mycotoxin-producing fungus, has also been associated with ferulic acid content of corn (Assabgui et al. 1993).

The objective of our study was to determine the susceptibility to maize weevils of 8 inbred corn lines relatively resistant to infection by $A$. flavus (Scott and Zummo 1988). Maize weevils were chosen for the study because they are a major pest of stored corn throughout the corn-growing regions of the world (Throne 1986). We also determined whether infection of com by $A$. flavus in the field and biological parameters of maize weevils on stored corn are correlated with several chemical and physical properties of the stored corn.

\section{Materials and Methods}

Corn Lines. The lines used in this study differed in their susceptibility to kernel infection by A. flavus in the field (Scott and Zummo 1988). Reported kernel infection levels were $5.6 \%$ for Mp313E, $6.0 \%$ for SC54, 6.1\% for Mp420, 6.4\% for Mol8W, $7.8 \%$ for SC76, 8.7\% for TX601, $11.0 \%$ for $\mathrm{Mp} 317,12.7 \%$ for $\mathrm{SC229}, 16.8 \%$ for Mp68:616, and 30.1\% for SC212M. 'Pioneer 3320', 
Table 1. Biological parameters, mean \pm SD, of maize weevils reared on corn lines differing in their susceptibility to $A$. flavus infection

\begin{tabular}{|c|c|c|c|c|c|}
\hline Conn line & $\begin{array}{l}\text { No. } \\
\text { eggs laida }\end{array}$ & $\begin{array}{c}\text { Duration of } \\
\text { development, } \mathrm{d}^{b}\end{array}$ & $\begin{array}{l}\text { Progeny } \\
\text { producedc }\end{array}$ & Survivorship ${ }^{d}$ & $\begin{array}{c}\text { Susceptibility } \\
\text { index }\end{array}$ \\
\hline MolsW (R) & $53.0 \pm 3.61$ & $33.1 \pm 1.11 \mathrm{ab}$ & $42.7 \pm 5.5 \mathrm{l} a b$ & $0.81 \pm 0.11$ & $0.1 .13 \pm 0.0066 \mathrm{bcd}$ \\
\hline Mp313E (R) & $65.7 \pm 7.02$ & $31.2 \pm 0.18 \mathrm{c}$ & $51.7 \pm 5.86 a$ & $0.79 \pm 0.06$ & $0.1 .26 \pm 0.0040 a$ \\
\hline Mp317 (R) & $52.7 \pm 10.21$ & $31.6 \pm 0.93 \mathrm{bc}$ & $37.3 \pm 7.23 \mathrm{bc}$ & $0.71 \pm 0.03$ & $0.114 \pm 0.0085 \mathrm{bcd}$ \\
\hline $\mathrm{Mp} 420(\mathrm{R})$ & $46.7 \pm 3.21$ & $33.5 \pm 0.75 a$ & $34.7 \pm 5.51 \mathrm{bc}$ & $0.74 \pm 0.10$ & $0.106 \pm 0.0050 \mathrm{~d}$ \\
\hline$S C 54(R)$ & $56.0 \pm 5.66 f$ & $34.0 \pm 1.71 \mathrm{a}$ & $37.0 \pm 4.24 \mathrm{bof}$ & $0.64 \pm 0.04$ & $0.1 .09 \pm 0.0062 \mathrm{~cd}^{f}$ \\
\hline SC.76 (R) & $48.0 \pm 8.00$ & $30.8 \pm 1.62 \mathrm{~cd}$ & $36.0 \pm 2.65 b \mathrm{~b}$ & $0.76 \pm 0.10$ & $0.117 \pm 0.0082 \mathrm{abc}$ \\
\hline SC,229 (R) & $55.3 \pm 4.93$ & $31.6 \pm 0.40 \mathrm{bc}$ & $40.7 \pm 0.58 \mathrm{bc}$ & $0.74 \pm 0.07$ & $0.1 .17 \pm 0.001 .9 \mathrm{abc}$ \\
\hline TX601 (R) & $51.0 \pm 2.83$ & $31.9 \pm 0.97 b c$ & $38.0 \pm 4.24 \mathrm{bc} f$ & $0.69 \pm 0.13$ & $0.116 \pm 0.0008 a b c d /$ \\
\hline Mp68:616 (S) & $55.0 \pm 12.73^{f}$ & $29.4 \pm 0.63 \mathrm{~d}$ & $40.0 \pm 9.90 \mathrm{bc} f$ & $0.79 \pm 0.10$ & $0.124 \pm 0.0068 \mathrm{ab} f$ \\
\hline SC $212 M(S)$ & $44.7 \pm 9.61$ & $32.9 \pm 0.54 \mathrm{ab}$ & $31.7 \pm 4.73 c$ & $0.72 \pm 0.05$ & $0.105 \pm 0.0027 d$ \\
\hline Piomerer 3320 (NI) & $45.5 \pm 6.36 f$ & $30.6 \pm 0.05 \mathrm{~cd}$ & $32.0 \pm 0.00 \mathrm{be} f$ & $0.70 \pm 0.07$ & $0.113 \pm 0.0002 \mathrm{hod}^{\prime}$ \\
\hline MSIDH & $-a$ & 1.60 & 10.9 & $-d$ & 0.011 \\
\hline
\end{tabular}

Ietters after the names of the corn lines indicate whether the lines are relatively resistant (R) or susceptible (S) to A. flavtes infection, or whether susceptibility has not been determined (ND). Means within a column followed by the same letter are not significantly different $[\alpha=0.05$; Waller-Duncan $k$-ratio test, $k=100$ (SAS Institute 1988)].

$"$ Number of eggs laid did not vary with corn line $(F=1.93 ; \mathrm{df}=10,18 ; P=0.11)$

'Duration of development varied with corn line $(F=6.43 ; \mathrm{df}=10,22 ; P<0.01)$.

- Number of progeny produced varied with corn line $(F=3.27 ; \mathrm{df}=10,18 ; P=0.01)$.

"Survivorship from egg to adult emergence did not vary with corn line $(F=1.01 ; \mathrm{df}=10,22 ; P=0.47)$.

"The I Dobis index of susceptibility varied with corn line $(F=4.00$; df $=10,18 ; P=0.01)$.

$f$ This mean is based on 2 observations. Other means are based on 3 observations.

A A confidence interval can be calculated to determine by how much any 2 means differ. Calculate the confidence interval as /metan, - meand \pm MSD, where MSD (shown at the bottom of each column) is the minimum significant difference calculated using the Waller-1 Duncan $k$-ratio test. For example, for duration of development on SC54 and Mp68:616, the confidence interval is |34.0 - $29.4 \mid$ \pm 1.60 , or 3.0 to 6.2 . Thus, the true difference between the 2 means is between 3.0 and $6.2 \mathrm{~d}$.

a commercial dent corn hybrid commonly grown in the southeastern United States, was also included; however, we do not know its susceptibility to A. flavus infection.

Insect Development. Weevils were from a culture maintained at $25 \pm 1{ }^{\circ} \mathrm{C}, 65-70 \% \mathrm{RH}$, and a photoperiod of 12:12 (L:D) h. The culture was founded with weevils collected from grain storage areas in southern South Carolina in 1985, and weevils from the field were added to the culture monthly. Weevil generations were separated so that weevils only recently removed from the field were used for experiments. Voucher specimens were placed in the Florida State Collection of Arthropods (numbers.JT1-JT6).

The corn was X-rayed (Throne 1994) to ensure that no insects were present. Lots of $30.0 \pm 0.1 \mathrm{~g}$ of each corn line were placed individually in each of three 40-dram vials. A 35-mm-diameter hole in the bottom of the vial and in the lid were covered with 64- $\mu$-mesh nylon screen for ventilation. These vials were placed randomly on a perforated false floor in 3 covered plastic boxes ( 40 by 27.5 by 16 $\mathrm{cm}$ high; 1 replication of each corn line in each box). The boxes each contained a saturated sodium chloride ( $\mathrm{NaCl}$ ) solution below the false floor to maintain relative humidity at $75 \%$ (Greenspan 1977). An additional cage containing a 300-g sample of Pioneer 3320 corn was placed in each box and the moisture content of those $300-\mathrm{g}$ samples was measured weekly with a moisture tester (Motomco model 919 automatic grain moisture tester, Dickey-John, Auburn, IL). The boxes were placed in an environmental chamber maintained at $30 \pm$ $1^{\circ} \mathrm{C}$ and a photoperiod of 12:12 (L:D) $h$, and the corn was equilibrated for 6 wk to these conditions before the insect bioassays were conducted.

After the 6-wk equilibration period, 5 females (3- to 4-wk-old $F_{3}$ ) were placed in each cage. Sex was determined by snout characteristics (Tolpo and Morrison 1965) after immobilization of weevils by chilling. Females were sieved from the cages after $72 \mathrm{~h}$ using a U.S. standard no. 6 sieve (3.36-mm openings), and species and sex were confirmed based on examination of genitalia ( $\mathrm{Hal}-$ stead 1962) because of the external morphological similarity of the maize weevil to the rice weevil, $S$. oryzae (L.). Starting $2 \mathrm{wk}$ after females were removed, emerging adult progeny were sieved from the corn every day. After all adults had emerged, each lot of corn was X-rayed (Throne 1994) to determine the presence of any weevil stage. This allowed us to determine number of eggs laid and rate of survival from egg to adult emergence.

An index (Dobie 1974) was used to compare the susceptibility to maize weevils of the corn lines. This index is calculated as $\left(\log _{e} Y\right) / T$, where $Y=$ number of progeny produced on a given corn line and $T=$ duration of development on that corn line. This index incorporates number of eggs laid, survival to the adult stage, and development time because number of progeny produced is based on the number of eggs laid and survival to the adult stage. Larger index values indicate greater susceptibility to maize weevils. Dobie (1974) suggested that this index approaches the intrinsic rate of increase, $r_{m}$. We used the susceptibility index as an 
Table 2. Predieted number of adult maize weevils when 1 pair is reared for up to $180 \mathrm{~d}$ on corn lines differing in their susceptibility to $A$. flavus infection

\begin{tabular}{lccr}
\hline \multirow{2}{*}{ Corn line } & \multicolumn{3}{c}{ Day } \\
\cline { 2 - 4 } & 60 & $120^{a}$ & $180^{\circ}$ \\
\hline SC212M (S) & 1,070 & 0.57 & 310 \\
Mp420 (R) & 1,122 & 0.63 & 350 \\
SC54 (R) & 1,401 & 0.98 & 690 \\
Pioneer 3320 (ND) & 1,771 & 1.57 & 1,390 \\
Mo.18W (R) & 1,792 & 1.61 & 1,440 \\
Mp317 (R) & 1,892 & 1.79 & 1,690 \\
TX601 (R) & 2,057 & 2.12 & 2,180 \\
SC76 (R) & 2,198 & 2.42 & 2,650 \\
SC229 (R) & 2,278 & 2.60 & 2,960 \\
Mp68:616 (S) & 3,325 & 5.53 & 9,190 \\
Mp313E (R) & 3,933 & 7.73 & 15,210 \\
\hline
\end{tabular}

Letters after the names of the corn lines indicate whether the lines are relatively resistant $(R)$ or susceptible $(S)$ to A. flatus infection, or whether susceptibility hass not been determined (ND).

a Predicted number of maize weevils after 120 and 180 days, in millions.

estimate of $r_{m}$ to calculate population growth over a 6-mo storage period as:

$$
N_{t}=N_{t-1} e^{r_{m} t}
$$

where $N_{t}=$ number of weevils at time $t$.

Chemical and Physical Analyses. Relative size of kernels was determined by counting the number of kernels in each of three 10-g samples of each corn line. Lots of $15.0 \pm 0.1 \mathrm{~g}$ of each corn line were equilibrated at $30^{\circ} \mathrm{C}$ over an $\mathrm{NaCl}$ solution for use in determining kernel hardness and equilibrium moisture content. Relative kernel hardness was determined by grinding 3 replicates $(3.0 \pm 0.1$ g each) of each corn line in a 50 -ml cup of a blender for $20 \mathrm{~s}$, and determining the ratio of the portion of the corn held over a U.S. standard no. 35 sieve $(0.5-\mathrm{mm}$ openings $)$ to the portion passing through the sieve (Dobie 1974). Equilibrium moisture content was determined using the air-oven method (method 44-15A, AACC 1969) and was assumed to be indicative of equilibrium moisture content in the insect bioassays.

Lots of $30.0 \pm 0.1 \mathrm{~g}$ of each corn line were ground over a U.S. standard no. 40 sieve $(0.425$ mm openings) in a laboratory mill and analyzed for total Kjeldahl nitrogen, soluble nitrogen, soluble carbohydrate, total lipid, soluble free phenolics, and bound phenolics. Total Kjeldahl nitrogen determined by the method of Lang (1958) was based on analysis of 6 replicate $10-\mathrm{mg}$ samples of each corn line, and expressed as percentage of protein $(N \times 6.25)$ based on sample dry weight.

Soluble nitrogen was determined by extracting $100 \mathrm{mg}$ samples of each corn line 5 times with 1 $\mathrm{ml} 0.15 \mathrm{M} \mathrm{NaCl}$ followed by brief centrifugation, combining supernatants, and analyzing 1-ml aliquots by the method of Lang (1958). Results are based on 4 replicates of each com line and expressed as a percentage of dry weight.
Table 3. Physical properties, mean \pm SD, of corn lines differing in their suseeptibility to $A$. flavus infection

\begin{tabular}{lccc}
\hline \hline Corn line & $\begin{array}{c}\text { Kernel } \\
\text { hardness }^{a}\end{array}$ & $\begin{array}{c}\text { \% Moisture } \\
\text { content }^{\text {d }}\end{array}$ & $\begin{array}{c}\text { No. } \\
\text { kernels }\end{array}$ \\
\hline Mo18W (R) & $2.43 \pm 0.26 \mathrm{~d}$ & $13.9 \pm 0.10$ & $47.0 \pm 1.73 \mathrm{c}$ \\
Mp313E (R) & $2.03 \pm 0.15 \mathrm{f}$ & $13.9 \pm 0.31$ & $30.0 \pm 0.00 \mathrm{~g}$ \\
Mp317 (R) & $2.15 \pm 0.08 \mathrm{ef}$ & $14.2 \pm 0.01$ & $40.3 \pm 0.581$ \\
Mp420 (R) & $2.89 \pm 0.15 \mathrm{~b}$ & $13.5 \pm 0.28$ & $39.3 \pm 0.58 \mathrm{f}$ \\
SC54 (R) & $3.38 \pm 0.20 \mathrm{a}$ & $13.6 \pm 0.24$ & $49.7 \pm 1.15 \mathrm{~d}$ \\
SC76 (R) & $2.72 \pm 0.04 \mathrm{bc}$ & $13.8 \pm 0.34$ & $57.0 \pm 2.00 \mathrm{~b}$ \\
SC229 (R) & $3.37 \pm 0.19 \mathrm{a}$ & $13.8 \pm 0.20$ & $52.3 \pm 1.53 \mathrm{c}$ \\
TX601 (R) & $2.37 \pm 0.25 \mathrm{de}$ & $13.8 \pm 0.65$ & $52.0 \pm 1.73 \mathrm{c}$ \\
Mp68:616 (S) & $2.87 \pm 0.22 \mathrm{~b}$ & $13.6 \pm 0.34$ & $64.3 \pm 1.53 \mathrm{a}$ \\
SC212M (S) & $2.48 \pm 0.12 \mathrm{~cd}$ & $13.7 \pm 0.38$ & $51.7 \pm 0.58 \mathrm{~cd}$ \\
Pioneer 3320 & & & \\
(ND) & $1.77 \pm 0.01 \mathrm{~g}$ & $14.8 \pm 0.15$ & $31.3 \pm 2.52 \mathrm{~g}$ \\
MSD $^{d}$ & 0.26 & $-b$ & 2.2 \\
\hline
\end{tabular}

Letters after the names of the corn lines indicate whether the lines are relatively resistant (R) or susceptible (S) to $A$. flatus infection, or whether susceptibility has not been determined (ND). Means within a column followed by the same letter are not significantly different, $k=100(\alpha=0.05$; Waller-Duncan $k$-ratio test [SAS Institute 1988]).

$a$ Kernel hardness varied with com line $(F=27.70$; $\mathrm{df}=10$, 22; $P<0.01 ; n=3$ ).

$b$ Equilibrium moisture content did not vary with corn line ( $F$ $=2.69 ; \mathrm{df}=10,11 ; P=0.06 ; n=2$ ).

$c$ Number of kemels per 10 -g sample varied with corn line ( $F$ $=158.41 ; \mathrm{df}=10,22 ; P<0.01 ; n=3$ ).

$d$ A confidence interal can be calculated to determine by how much any 2 means differ. Calculate the confidence interval as $\mid$ mean $_{1}-$ mean $_{2} \mid \pm$ MSD, where MSD (shown at the bottom of each column) is the minimum significant difference calculated using the Waller-Duncan $k$ ratio test. For examplex, for SC54 and Pioneer 3320 , the confidence interval for hardaess is $|3.38-1.77|$ \pm 0.26 , or 1.35-1.87. Thus, the true difference between the 2 hardness ratios is between 1.35 and 1.87 .

Soluble carbohydrate was determined by extracting 50-mg samples of each corn line 4 times with $5 \mathrm{ml} \mathrm{H}_{2} \mathrm{O}$ for $5 \mathrm{~min}$ at $80^{\circ} \mathrm{C}$. Supernatants were combined, brought to $50 \mathrm{ml}$ volume, and 200- $\mu$ l aliquots assayed for carbohydrate (as glucose) with the method of Dubois et al. (1956). Results are based on 5 replicates per com line and expressed as a percentage of dry weight.

Lipid content was estimated by extracting $5-\mathrm{g}$ samples of ground corn with $180 \mathrm{ml} \mathrm{n}$-hexane for $6 \mathrm{~h}$ in a Soxhlet extractor. Solvent was removed in tared $100-\mathrm{ml}$ flasks on a rotoevaporator, and extract weight determined. Results are based on extraction of 3 replicates of each corn line and expressed as a percentage of sample dry weight.

Free phenolic acids were extracted from $1-\mathrm{g}$ samples of the defatted ground corn (after lipid extraction) by the method of Krygier et al. (1982) and analyzed with the procedures of Swain and Hillis (1959) and Singleton and Rossi (1965). Results are based on 3 replicate samples of each corn line and expressed as chlorogenic acid equivalents.

Following removal of free phenolic acids, bound phenolics in the corn samples were released by alkaline hydrolysis and isolated with the procedures of Krygier et al. (1982) and Sosulski et al. (1982). Bound phenolic acids were analyzed and expressed as chlorogenic acid equivalents as above. 
Table 4. Chemieal properties, mean $\pm \mathrm{SD}$, of corn lines differing in their susceptibility to A. flavus infection

\begin{tabular}{|c|c|c|c|c|c|c|}
\hline Com line & $\begin{array}{c}\text { \% soluble } \\
\text { carbohydrate }\end{array}$ & $\%$ lipid $^{b}$ & $\begin{array}{l}\% \text { soluble } \\
\text { nitrogen }\end{array}$ & $\begin{array}{l}\text { \% bound } \\
\text { phenolics }\end{array}$ & $\begin{array}{c}\% \text { free } \\
\text { phenolics }\end{array}$ & $\%$ protein $f$ \\
\hline MolsW(R) & $10.7 \pm 1.85 \mathrm{ef}$ & $4.97 \pm 0.42 \mathrm{a}$ & $0.34 \pm 0.039 \mathrm{de}$ & $0.260 \pm 0.021 \mathrm{~b}$ & $0.143 \pm 0.021 \mathrm{de}$ & $12.8 \pm 0.38 \mathrm{~d}$ \\
\hline $\mathrm{Mp} 313 \mathrm{E}$ (K) & $14.0 \pm 1.30 \mathrm{ab}$ & $4.77 \pm 0.32 \mathrm{abc}$ & $0.38 \pm 0.039 \mathrm{bc}$ & $0.215 \pm 0.033$ bede & $0.190 \pm 0.010 \mathrm{ab}$ & $11.6 \pm 0.41 \mathrm{e}$ \\
\hline $\mathrm{Mp} 317(\mathrm{R})$ & $11.7 \pm 1.64 \mathrm{cde}$ & $3.97 \pm 0.32 \mathrm{~d}$ & $0.33 \pm 0.018 \mathrm{e}$ & $0.209 \pm 0.045 \mathrm{bcde}$ & $0.147 \pm 0.021 \mathrm{de}$ & $11.7 \pm 0.50 \mathrm{e}$ \\
\hline$M_{p 420}(\mathrm{R})$ & $12.8 \pm 0.72 b c$ & $4.90 \pm 0.44 \mathrm{ab}$ & $0.36 \pm 0.022 \mathrm{cde}$ & $0.354 \pm 0.035 \mathrm{a}$ & $0.207 \pm 0.012 \mathrm{a}$ & $14.3 \pm 0.89 \mathrm{c}$ \\
\hline Sc54 (R) & $9.8 \pm 0.18 f$ & $5.07 \pm 0.51 a$ & $0.47 \pm 0.017 \mathrm{a}$ & $0.247 \pm 0.001 \mathrm{bc}$ & $0.187 \pm 0.021 \mathrm{ab}$ & $17.2 \pm 0.74 a$ \\
\hline SC:76 (R) & $11.2 \pm 1.50 \mathrm{de}$ & $4.47 \pm 0.35 \mathrm{abed}$ & $0.37 \pm 0.015 \mathrm{~cd}$ & $0.205 \pm 0.017 \mathrm{bcde}$ & $0.150 \pm 0.010 \mathrm{~cd}$ & $13.0 \pm 1.03 \mathrm{~d}$ \\
\hline SC:229 (R) & $9.6 \pm 0.89 \mathrm{f}$ & $4.67 \pm 0.31 \mathrm{abed}$ & $0.35 \pm 0.015 \mathrm{de}$ & $0.238 \pm 0.013 \mathrm{bcd}$ & $0.100 \pm 0.017 f$ & $14.3 \pm 0.61 \mathrm{c}$ \\
\hline TX60)1 (I & $12.3 \mp 1.21 \mathrm{~cd}$ & $4.23 \pm 0.31 \mathrm{bcd}$ & $0.47 \pm 0.013 a$ & $0.191 \pm 0.027 \mathrm{de}$ & $0.123 \pm 0.006 \mathrm{ef}$ & $15.5 \pm 0.77 b$ \\
\hline Mp6s:616 (S) & $12.4 \pm 0.48 \mathrm{~cd}$ & $4.07 \pm 0.15 \mathrm{~cd}$ & $0.41 \pm 0.036 b$ & $0.259 \pm 0.003 \mathrm{~b}$ & $0.173 \pm 0.006 \mathrm{bc}$ & $12.7 \pm 0.58 \mathrm{~d}$ \\
\hline$S C: 212 M(S)$ & $12.2 \pm 1.28 \mathrm{~cd}$ & $4.80 \pm 0.53 \mathrm{ab}$ & $0.30 \pm 0.019 f$ & $0.196 \pm 0.035 \mathrm{cde}$ & $0.140 \pm 0.026 \mathrm{de}$ & $.12 .6 \pm 0.52 \mathrm{~d}$ \\
\hline Pioncer 3320 (ND) & $14.8 \pm 0.86 \mathrm{a}$ & $4.43 \pm 0.33 \mathrm{abcd}$ & $0.36 \pm 0.015 \mathrm{cde}$ & $0.162 \pm 0.026 \mathrm{e}$ & $0.138 \pm 0.010 \mathrm{de}$ & $8.5 \pm 0.44 f$ \\
\hline MSID & 1.3 & 0.72 & 0.03 & 0.045 & 0.025 & 0.6 \\
\hline
\end{tabular}

I Atters after the names of the corn lines indicate whether the lines are relatively resistant (R) or susceptible (S) to $A$. flatus infection, or whether susceptibility has not been determined (ND). Means within a column followed by the same letter are not significantly different ( $\alpha=0.05$; Waller-Duncan $k$ ratio test, $k=100$ [SAS Institute 1988]).

a Percentage soluble carbohydrate varied with corn line $(F=12.41$; $\mathrm{d} f=10,49 ; P<0.01 ; n=5$, except $n=10$ for Pioneer 3.320$)$.

$b$ Percentage lipid varied with corn line $(F=2.96 ; \mathrm{df}=10,23 ; P=0.02 ; n=3$, except $n=4$ for Pioneer 3320$)$.

c Perecntage soluble nitrogen varied with com line $(F=20.53$; df $=10,37 ; P<0.01 ; n=4$, except $n=8$ for Pioneer 3320$)$

"Percentage bound phenolics varied with com line $(F=8.54 ; \mathrm{df}=10,13 ; P<0.01 ; n=2$, except $n=4$ for Pioneer 3320$)$.

- Pereentage free phenolies varied with com line $(F=12.29 ; \mathrm{df}=10,23 ; P<0.01 ; n=3$, except $n=4$ for Pioneer 3320$)$.

$f$ Percentage protein varied with com line $(F=102.27 ; \mathrm{df}=10,61 ; P<0.01 ; n=6$, except $n=12$ for Pioneer 3320$)$.

i A confidence interval can be calculated to determine by how much any two means differ. Calculate the confidence interval as $\mid$ me'anl $\rightarrow$ meang \pm MSD, where MSD (shown at the bottom of each column) is the minimum significant difference calculated using the Waller-1Duncan $k$ ratio test. For example, for Pioneer 3320 and SC229, the confidence interval for percentage of soluble carlohydrate's is $|14.8-9.6| \pm 1.33$, or $3.87-6.53$. Thus, the true difference between the 2 means is between 3.87 and 6.53 .

Results are based on 2 replicate samples of each cultivar.

Statistical Analysis. The general linear models (GLM) procedure of SAS (SAS Institute 1987) was used to determine whether mean number of eggs laid by weevils; development time; number of progeny produced; Dobie index of susceptibility; survivorship from egg to adult emergence; kernel hardness; number of kernels per $10 \mathrm{~g}$ sample; or percentage protein, soluble nitrogen, soluble carbohydrate, lipid, free or bound phenolic acids, or equilibrium moisture content differed with corn line. The protein/carbohydrate ratio of the corn lines was included as an independent variable because it has been shown to be correlated with insect growth (Applebaum 1972). Variances for duration of development, Dobie index of susceptibility, soluble carbohydrate, kernel hardness, and bound phenolics were nonhomogeneous. However, equalizing variances by transformation changed $F$ values and probability levels very little; hence, untransformed data are reported in the tables.

The correlation procedure (CORR) of SAS (SAS Institute 1988) was used to determine whether any of the dependent variables (biological parameters of the weevils) were correlated with any of the independent variables (chemical and physical properties of the corn). The stepwise regression procedure (REG) of SAS (SAS Institute 1987) was used to determine regression coefficients for the relationships between dependent and independent variables, including models with multiple predictor variables. We used the same analyses to identify relationships between preharvest aflatoxin infection levels (Scott and Zummo 1988) and the chem- ical and physical properties of the dried corn and insect biology on the dried corn.

\section{Results}

Insect Development. Duration of maize weevil development, number of progeny produced, and the Dobie index of susceptibility differed with corn line (Table 1). However, differences in number of eggs laid and survivorship from egg-to-adult emergence were not detected among the corn lines. Decreased weevil development time indicates increased susceptibility of a corn line to this insect. The corn line on which weevil development was shortest, Mp68:616, is also highly susceptible to $A$. flavus infection. Maize weevil development time on corn lines SC54, Mp420, and Mol8W, which are relatively resistant to $A$. flavus infection, took 4-5 d longer than on Mp68:616.

More progeny were produced on Mp313E and Mol8W, which are relatively resistant to $A$. flavus infection. Fewest progeny were produced on $\mathrm{SC} 212 \mathrm{M}$, which is relatively susceptible to $A$. flavus infection. The Dobie index of susceptibility indicated that some of the corn lines that are less susceptible to A. flavus infection could be selected to limit weevil population growth (particularly Mp420 and SC54). There was nearly a 50-fold difference in predicted numbers of weevils present after $180 \mathrm{~d}$ on the various corn lines (Table 2).

Chemical Analyses. All of the chemical and physical properties varied with corn line, except equilibrium moisture content (Tables 3 and 4 ). Duration of maize weevil development increased with lipid content of the corn lines (Table 5), al- 
Table 5. Correlations $[r$ and $P(r>0)]$ among biological parameters of maize weevils reared on corn lines differing in their susceptibility to $A$. flavus infection and chemical and physical properties of the corn lines

\begin{tabular}{lccrrr}
\hline \hline $\begin{array}{c}\text { Physical or } \\
\text { chemical property }\end{array}$ & $\begin{array}{c}\text { No. } \\
\text { eggs laid }\end{array}$ & $\begin{array}{c}\text { Duration of } \\
\text { development }\end{array}$ & $\begin{array}{c}\text { Progeny } \\
\text { produced }\end{array}$ & \multicolumn{1}{c}{ Survivorship } & $\begin{array}{c}\text { Susceptibility } \\
\text { index }\end{array}$ \\
\hline Kernel hardness & $-0.01(0.95)$ & $0.28(0.118)$ & $-0.11(0.58)$ & $-0.10(0.57)$ & $-0.16(0.39)$ \\
\% moisture content & $-0.07(0.72)$ & $-0.29(0.100)$ & $-0.09(0.66)$ & $-0.08(0.66)$ & $0.11(0.58)$ \\
No. kernels/10g & $-0.19(0.34)$ & $-0.14(0.428)$ & $-0.23(0.23)$ & $0.03(0.87)$ & $-(0.04(0.85)$ \\
\% soluble carbohydrate & $-0.01(0.94)$ & $-0.34(0.050)$ & $0.04(0.83)$ & $0.09(0.63)$ & $0.14(0.48)$ \\
\% lipid & $0.04(0.84)$ & $0.64(0.000)^{*}$ & $0.10(0.61)$ & $-0.01(0.95)$ & $-0.31(0.11)$ \\
\% soluble nitrogen & $0.24(0.21)$ & $0.00(0.997)$ & $0.16(0.41)$ & $-0.22(0.21)$ & $0.25(0.20)$ \\
\% bound phenolics & $-0.02(0.94)$ & $0.36(0.040)$ & $0.03(0.87)$ & $0.14(0.42)$ & $-0.23(0.22)$ \\
\% free phenolics & $0.14(0.46)$ & $0.19(0.293)$ & $0.14(0.46)$ & $0.05(0.79)$ & $-0.02(0.90)$ \\
\% protein & $0.06(0.77)$ & $0.48(0.004)$ & $-0.02(0.91)$ & $-0.22(0.23)$ & $-0.21(0.28)$ \\
\% protein/\% carbohydrate & $0.18(0.60)$ & $0.54(0.088)$ & $0.02(0.96)$ & $-0.38(0.25)$ & $-0.23(0.50)$ \\
\hline
\end{tabular}

Numbers of observations are $33,29,33,29$, and 33 for number of eggs laid, duration of development, number of progeny produced, survivorship, and susceptibility index, respectively.

Asterisk indicates significance at the 0.05 table-wise error level $[\alpha /$ number of comparisons $=0.001$ (Rice 1989)]. Thus, a $P$ must be $<0.001$ to be significant at the 0.05 table-wise error level.

though the linear equation describing the relation$\operatorname{ship}(a=21.05 \pm 2.645, b=2.354 \pm 0.5713)$ explained only $38 \%$ of the variation among observations. Stepwise regression analyses indicated no significant $(P<0.05)$ predictors for other dependent variables. Levels of $A$. flavus infection in the field were not correlated with insect biology or chemical and physical properties of the corn lines $(P \geq 0.17$ for all correlations).

\section{Discussion}

Among the corn lines tested that were less susceptible to A. flavus infection, some were also less susceptible to maize weevils. Weevil development time varied by $5 \mathrm{~d}$ among corn lines, and number of progeny produced could be halved based on the corn line selected. Weevils reared on some of the lines less susceptible to $A$. flavus infection had both relatively low progeny production and longer developmental time. Long-term maize weevil population growth was $\approx 25$ - to 50 -fold greater on Mp313E than on SC54 or Mp420. Further development of corn lines that are less susceptible to both A. flavus and to maize weevils would be desirable. Development of corn lines that are susceptible to $A$. flavus infection and to infestation by maize weevils, such as Mp68:616, should be avoided. We have shown in this study, and in a previous study (Throne 1989), that use of corn lines that limit insect growth can severely limit insect population levels in stored corn during a normal storage period which results in less damage to the com and may reduce the cost of insect control.

Maize weevil fecundity, progeny production, and Dobie index of susceptibility previously were shown to be correlated with protein and ferulic acid (a phenolic acid) content of corn (Classen et al. 1990). Protein content was the best predictor of progeny production and fecundity, and ferulic acid content was the best predictor of Dobie index. Our results differed in that only development time could be predicted based on chemical and physical properties of the corn, and lipid content was the best predictor. We did not measure ferulic acid content of the corn lines, but ferulic acid accounts for $65-85 \%$ of total phenolics in corn (Classen et al. 1990, Sosulski et al. 1982). Bound phenolics constitute $\approx 70 \%$ of total phenolics in corn (Sosulski et al. 1982), therefore our measurements of bound phenolic acids may be indicative of ferulic acid content. Kernel hardness has previously been shown to be correlated with susceptibility to maize: weevil infestation (Dobie 1974); we did not find this to be the case in our study.

Infection of com in the field by $F$. graminearum was shown to be negatively correlated with ferulic acid content of corn and positively correlated with $p$-coumaric acid content, both of which are phenolic acids (Assabgui et al. 1993). We did not find any correlation between $A$. flavus infection of corn and any of the chemical or physical properties we measured in the stored corn. These properties may differ from those of preharvest corn. It is possible that a chemical or physical factor may be found in preharvest corn that can be used to predict the resistance of corn to A. flavus infection.

\section{Acknowledgments}

We thank Julia A. Barron, Patricia L. Lang, and Stanley M. Woo (USDA-ARS, Savannah, GA) for technical assistance; Victor Chew (USDA-ARS, Gainesville, FL) for advice on the statistical analyses; and Patrick F. Dowd (USDA-ARS, Peoria, IL) and Robert L. Meagher, Jr. (University of Minnesota) for reviewing an earlier version of the manuscript.

\section{References Cited}

American Association of Cereal Chemists. 1969. Approved methods of the American Association of Cereal Chemists. American Association of Cereal Chemists, St. Paul, MN.

Applehaum, S. W. 1972. The carbohydrate nutrition of Tribolitum, pp. 288-297. In J. G. Rodriguez [ed.], Insect and mite nutrition, significance and implica- 
tions in ecology and pest management. North-Holland, Amsterdam.

Assabgui, R. A., L. M. Reid, R. I. Mamilton, and J. T. Arnason. 1993. Correlation of kernel (E)-ferulic acid content of maize with resistance to Fusarium gramincamum. Phytopathology 83: 949-953.

Clussen, D., J. T. Arnason, J. A. Serratos, J.D.H. Lambert, C. Nozzolillo, und B.J.R. Philogène. 1990. Correlation of phenolic acid content of maize to resistance to Sitophilus zeamais, the maize weevil, in CIMMYT's collections. J. Chem. Ecol. 16: 301-315.

Dobie, P. 1974. The laboratory assessment of the inherent susceptibility of maize varieties to postharvest infestation by Sitophilus zeamais Motsch. (Coleoptera, Curculionidae). J. Stored Prod. Res. 10: 183197.

Dowd, P. F. 1994. Examination of an Aspergillus flavus resistant inbred of maize for cross-resistance to sap beetle vectors. Entomol. Exp. Appl. 71: 177-180.

Dulsois, M., K. A. Gilles, J. K. Hamilton, P. A. Rebers, and F. Smith. 1956. Colorimetric method for determination of sugars and related substances. Anal. Chem. 28: 350-356.

Greenspan, L. 1977. Humidity fixed points of binary saturated aqueous solutions. J. Res. Natl. Bur. Stand. A81: $89-96$

Halstend, D.G.H. 1962. The rice weevils, Sitophilus oryzal? (L.) and Sitophilus zeamais Mots.; identification and synonymy. Trop. Stored Prod. Inf. 5: 177179 .

Krygier, K., F. Sosulski, and L. Hogge. 1982. Free, esterified, and insoluble-bound phenolic acids. 1. Extraction and purification procedure. J. Agric. Food Chem. 30: 330-334.

Lany, C. A. 1958. Simple microdetermination of Kjeldahl nitrogen in biological materials. Anal. Chem. 30: 1692-1694.

Rice, W. R. 1989. Analyzing tables of statistical tests. Evolution 43: 223-225.
SAS Institute. 1987. SAS/STAT guide for personal computers, version 6 ed. SAS Institute, Cary, NC.

1988. SAS procedures guide, version 6.03 ed. SAS Institute, Cary, NC.

Scott, G. E. and N. Zummo. 1988. Sources of resistance in maize to kernel infection by Aspergillus favus in the field. Crop Sci. 28: 504-507.

Singleton, V. L. and J. A. Rossi. 1965. Colorimetry of total phenolics with phosphomolybdic-phosphotungstic acid reagents. Am. J. Enol. Vitic. 16: 144-158.

Sinha, K. K. and A. K. Sinha. 1992. Impact of stored grain pests on seed deterioration and aflatoxin contamination in maize. J. Stored Prod, Res. $28: 211-219$.

Sosulski, F., K. Krygier, and L. Hogge. 1982. Free, esterified, and insoluble-bound phenolic acids. 3 . Composition of phenolic acids in cereal and potato flours. J. Agric. Food Chem. 30: 337-340.

Swain, T, and W. E. Hillis. 1959. The phenolic constituents of Prunus domestica I. The quantitative analysis of phenolic constituents. J. Sci. Food Agric. 10: 63-68.

Throne, J. E. 1986. A bibliography of maize weevils, Sitophilus zeamais Motschulsky (Coleoptera: Curculionidae). U.S. Dep. Agric., Agric. Res. Serv. 58.

1989. Effects of noncatastrophic control technologies that alter life history parameters on insect population growth: a simulation study. Environ. Entomol. 18: 1050-1055.

1994. Life history of immature maize weevils (Coleoptera: Curculionidae) on com stored at constant temperatures and relative humidities in the laboratory. Environ. Entomol. 23: 1459-1471.

Tolpo, N. C. and E. O. Morrison. 1965. Sex determination by snout characteristics of Sitophilus zeamais Motschulsky. Tex. J. Sci. 17: 122-124.

Received for publication 20 October 1994; accepted 17 April 1995. 